\title{
Effect of Ginkgo Biloba Leaves Extract on Some Formaldehyde Induced Toxicity in hippocampus of Adult Male Albino Rats
}

\author{
Amal Mohamad Abd El-Khalekª and Amal Al Shahat Ibrahim²
}

${ }^{1}$ Department of Forensic Medicine and Clinical Toxicology
${ }^{2}$ Department of Anatomy

Faculty of Medicine, Zagazig University, Zagazig, Egypt.

\begin{abstract}
Formaldehyde (FA) heavily impacts the everyday consumer products. It is widely used in the construction, textile, furniture, medical, chemical, and pharmaceutical industries. Exposure to FA poses a significant threat to public health. It can cause severe central nervous system impairment. Extract from the leaves of Ginkgo biloba exerts a novel spectrum of biological, pharmacological and therapeutic properties against oxidative stress, so it was of special concern to investigate the role of Ginkgo biloba leaves extract (GBE) on the neurotoxic effects of FA on hippocampus of adult male albino rats. Thirty adult male albino rats were used in the present study. They were divided into 5 equal groups: Group I negative control, Group II received distilled water by intraperitoneal (i.p.) injection. Group III received GBE (300 mg/kg/day) orally. Group IV received FA $(0.2 \mathrm{mg} / \mathrm{kg} /$ day i.p. and Group V received 0.2 $\mathrm{mg} / \mathrm{kg} \mathrm{FA}+300 \mathrm{mg} / \mathrm{kg} \mathrm{GBE}$. After the end of the study ( 4weeks), all rats were sacrificed and brain were dissected out and hippocampus subjected to estimation of superoxide dismutase (SOD), glutathione peroxidase (GSH-Px) catalase (CAT) and malondialdehyde (MDA) levels. Histological examination of the hippocampus and immunohistochemical staining for Glial fibrillary acidic protein (GFAP) were also done. The results of this study revealed that, the levels of SOD, CAT and GSH-Px were significantly decreased, while MDA level in hippocampus tissue were significantly increased in rats treated with FA compared to those of the controls. Microscopic examination of neurons of the hippocampus in this group revealed picnotic nuclei, vacuolar degeneration and neuronal loss. Immunostaining showed areas with significantly increased GFAP immunopositivity. Concomitant administration of GBE with FA resulted in a significant increase in antioxidant enzymes activity (SOD, GSH-Px and CAT), decreased MDA, and improvement of histopathological changes induced by FA. Also a significant reduction in expression of GFAP was observed. It was concluded that short term administration of FA induced neurotoxicity on the hippocampus of adult male albino rats, with oxidant stress and lipid peroxidation which may be a molecular mechanism involved in FA induced neurotoxicity. Furthermore, these effects were decreased by the concomitant use of GBE. It is recommended to use GBE for amelioration of toxic manifestations of formaldehyde in exposed population.
\end{abstract}

\section{Introduction}

$\mathrm{F}$ Tormaldehyde (FA), a member of the aldehyde family, is a common environmental pollutant (Luo et al., 2012). The body can encounter environmental FA, since a number of commonly used products contain either formaldehyde or formaldehydereleasing substances (de Groot et al., 2009). It is widely used in many products, including disinfectants, cosmetics, antiseptics and fungicides. It is also used in the manufacture of plastics, resins and building materials, such as particle board, plywood, floor coverings and office furniture, and it is emitted by cigarette smoking (Maiellaro et al., 2014). Hair smoothing products containing methylene glycol (or other FA donors or releasers) require the use of heat. Heat leads to volatilization of both FA gas as well as methylene glycol vapors increasing the potential for hair stylist and consumer exposure to FA from 
methylene glycol formulated in keratin products (Golden and Valentini, 2014).

Formaldehyde is toxic to the majority of organisms due to its non-specific reactions with macromolecules such as proteins, nucleic acids and lipids to form crosslinks, thereby leading to the loss of their biological functions (Zeng et al., 2014). As an effective cross-linking agent FA is used in certain vaccines to inactivate viruses and to detoxify bacterial toxins while not materially affecting antigenicity (Mitkusa et al., 2013). Formaldehyde can be added illegally as a food preservative and antimicrobial agent (Yeh et al., 2013). It is added to milk in the production of cheese and dairy products (Afifi and Hanon, 2011)

The term "formalin" refers to solutions of formaldehyde dissolved in water. Methanol is added as a stabilizer to prevent polymerization of formaldehyde into paraformaldehyde (Doane and Sarenbo, 2014). Now formaldehyde had been definitely the most common known indoor and outdoor air pollutant (Tang et al., 2012; Meng et al., 2014).

Thus, this ubiquitously present compound can enter the human body by inhalation, ingestion, or entry through the skin. (Tulpule and Dringen, 2013). Formaldehyde dehydrogenase catalyze the oxidation of formaldehyde in the tissues into formic acid and the highly toxic methanol (Katsnelson et al., 2013). Therefore formaldehyde serves as a well-documented source of methyl groups, which are transferred via tetrahydrofolate into the one-carbon pool for incorporation via biosynthesis into various macromolecules damaging it (Golden and Valentini, 2014).

The effect of FA on people is well known: irritation of the eyes and upper respiratory tract, headache, nausea, drowsiness, and allergic skin reactions. Prolonged exposure to FA can cause serious health effects such as immune system disorders, as well as asthma and nasopharyngeal cancer (Wang et al., 2012a). Many studies have been undertaken on the impacts of FA on the central nervous system. Epidemiological data showed that histology technicians exhibited reduced performance on story memory, digit span, increased errors on trails and they presented excessive fatigue and difficulty in remembering. Animal studies showed interventional effects of FA exposure on psychology and cognition (Liu et al., 2010). Tang et al. (2012) reported that FA is a neurotoxic molecule, capable of damaging the hippocampus of rats causing behavioral, learning and memory disorders

Oxidative damage was one of the most critical effects of formaldehyde exposure. It occurred in various organs of animals which were exposed to formaldehyde (Tang et al., 2013).

The use of traditional medicine is wide-spread throughout the world and plants remain a large source of natural antioxidants that might serve as leads for the development of novel drugs (Mengome et al., 2014).

Ginkgo biloba (Ginkgoaceae) is an important and widely used herb of the Chinese traditional medicine. It was known to have a variety of biological and pharmacological properties that made it useful as a cardioprotective, antiasthmatic, and antidiabetic agent (Jain et al., 2011). In addition, it had been shown to possess neuroprotective properties against hypoxia, ischemia, seizure activity and peripheral nerve damage. In accordance, it was shown - in clinical researches - to be effective in treating dementia in Alzheimer's disease and in enhancing memory and cognition and improving the capacity of geriatric patients to cope with the stressful demands of daily life (Abousetta et al., 2014).

Ginkgo biloba leaf extract (GBE) is available as film-coated tablets, oral liquids, and injectable solutions. In Europe GBE is primarily regulated as herbal medicine, but in the US as a dietary supplement. The pharmacological modes of action include antioxidant effects, radical scavenging, inhibition of platelet activating factor, alterations in membrane fluidity (signal transduction), and inhibition of glucocorticoid synthesis (Diamond and Bailey, 2013 ; Pereir et al., 2013).

The identified pharmacodynamic effects of GBE are clearly linked to terpene trilactones [ginkgolides A, B, and C and bilobalide] and flavonoid glycosides [quercetin, kaempferol, isorhamnetin] (Xiong et al., 2014).

The present study has been designed to explore the effect of GBE against some of FA toxicities on the hippocampus of adult male albino rats.

\section{Material and methods}

\section{Material}

\section{1-Chemicals}

- Formaldehyde (FA): formalin 37\% was obtained from Merck, Darmstadt, Germany.

- Ginkgo bilobaleaf extract (GBE): commercially obtained as Gencofar tablets (Pharco Pharmaceuticals).

- Kits for immunohistochemistry were supplied by Dako, Carpinteria CA, USA.

\section{2-Animals}

The study was conducted on thirty adult male albino rats. Their weight ranged from $180-200 \mathrm{gm}$ each. The rats were obtained from the breading animal house, faculty of Veterinary Medicine, Zagazig University. All rats were housed under similar conditions. The rats were fed commercial rodent pellets and given water ad libitum throughout the experiment.

\section{Ethical consideration of the study}

The study was conducted according to the guide for care and use of laboratory animals. All 
ethically approved considerations for animal housing and handling were considered.

The experimental protocol used followed the regulations for administration and for painless scarification of the experimental animals. The animals were acclimated in the animal house for a week before the start of the study.

\section{3-Expermental design}

The rats were divided into five equal groups.

\section{Group I (Negative control)}

The animals of this group left on ordinary rat diet and didn't receive any chemicals and were used to determine the basic values of the tested parameters.

\section{Group II (Distilled water group)}

The rats in this group was given $0.5 \mathrm{ml}$ distilled water daily by intraperitoneal (i.p.) injection and used as positive control group.

\section{Group III (GBE group)}

The rats in this group were given GBE 300 $\mathrm{mg} / \mathrm{kg} /$ day by gastric gavage (Naidu et al., 2000). The human therapeutic dose ranges from 80 to $720 \mathrm{mg} / \mathrm{d}$ for durations of 2 weeks to 2 years (Diamond and Bailey, 2013). The higher dose used in the study was due to the fact that GBE is a potent inducer of hepatic xenobiotic biotransformation enzymes in the rats (Sugiyama et al., 2004). Gencofar tablets contain 40 $\mathrm{mg}$ of GBE. One and half tablets $(60 \mathrm{mg} / \mathrm{rat})$ were ground well and suspended in $2 \mathrm{ml}$ distilled water, then the suspension was administered to the rat by gastric gavage.

\section{Group IV (FA group)}

The rats of this group received FA 0.2 $\mathrm{mg} / \mathrm{kg} /$ day by i.p injection [1/10 of LD50 of FA] (Odeigah, 1997). According to the manufacture; formalin is $37 \%$ by weight and $40 \%$ by volume. So, $1 \mathrm{ml}$ formalin contains $0.4 \mathrm{~g}$ FA. One $\mathrm{ml}$ of formalin was diluted with distilled water up to $1000 \mathrm{ml}$. In the new concentration $1 \mathrm{ml}$ contained $0.4 \mathrm{mg}$ FA. One $\mathrm{ml}$ then was diluted with distilled water up to $5 \mathrm{ml}$ and every rat received $0.5 \mathrm{ml}$ by i.p. injection. Doane and Sarenbo, (2014) stated that ingestion of small amounts of $36 \%$ formalin causes corrosive damage to the pharyngeal mucosa, epiglottis and esophagus leading to nausea, vomiting and discomfort, with a substantial risk of bleeding and perforation. So the i.p. route was chosen in the present study.

\section{Group V (FA + GBE group)}

The rats of this group was given GBE 300 $\mathrm{mg} / \mathrm{kg}$ orally + FA $0.2 \mathrm{mg} / \mathrm{kg} /$ day i.p.

The period of the study was 4 weeks. Twenty four hours after the last treatment, rats were anaesthetized by ether inhalation and were sacrificed. The brain were quickly dissected out and washed free of blood with ice cold saline. Hippocampus region was taken. The hippocampus is located in the medial temporal lobe, underneath the cortical surface. In the rat, the two hippocampi resemble a pair of bananas, joined at the stems by the hippocampal commissure that crosses the midline under the anterior corpus callosum. Different neuronal cell types are neatly organized into layers in the hippocampus (Pearce, 2001; Amaral and Lavenex, 2006). Some of the tissue specimens were used for oxidant enzymes assays while the rest of hippocampus region were subjected to histopthological examination and immunohistochemical staining for Glial fibrillary acidic protein (GFAP).

\section{Methods}

\section{I- Biochemical analysis}

\section{Preparation of brain tissue samples}

This was done according to (Farbiszewiski et al., 2000): tissues were homogenized in a four volumes of ice-cold Tris- $\mathrm{HCl}$ buffer $(50 \mathrm{mM}, \mathrm{pH} 7.4)$ using a homogenizer for $2 \mathrm{~min}$ at $5000 \mathrm{rpm}$, Levels of malondialdehyde (MDA), and CAT activity were determined in this homogenate. Also some of the homogenate was taken, centrifuged and its supernatant was separated. The supernatant solution was extracted with an equal volume of an ethanol/chloroform mixture $(5 / 3$, volume per volume $[\mathrm{v} / \mathrm{v}])$. After centrifugation at 5000 _ $g$ for $30 \mathrm{~min}$, the supernatant was taken and used in the SOD activity measurement.

\section{SOD activity determination}

Super oxide dismutase (SOD; EC 1.15.1.1) was assayed according to Misra and Fridovich (1972). The assay procedure involves the inhibition of epinephrine auto-oxidation in an alkaline medium $(\mathrm{pH}$ 10.2 ) to adrenochrome, which is markedly inhibited by the presence of SOD. Epinephrine was added to the assay mixture, containing tissue supernatant and the change in extinction coefficient was followed at 480 $\mathrm{nm}$ in a Spectrophotometer. Activity was expressed as units per $\mathrm{mg}$ protein.

\section{CAT activity determination}

The enzyme catalase (CAT; EC 1.11.1.6) converts $\mathrm{H} 2 \mathrm{O} 2$ into water. The CAT activity in plasma and tissue supernatant was measured spectrophotometrically at $240 \mathrm{~nm}$ by calculating the rate of degradation of $\mathrm{H} 2 \mathrm{O} 2$, the substrate of the enzyme (Johansson and Borg, 1988). Activity was expressed as units per mg protein.

\section{activity}

\section{Determination of glutathione peroxidase}

Glutathione peroxidase (GSH-Px, EC 1.6.4.2) activity was measured by the method of Paglia and Valentine (1967). The enzyme reaction in the tube containing NADPH, reduced glutathione (GSH), sodium azide and glutathione reductase was initiated by addition of $\mathrm{H} 2 \mathrm{O} 2$, and the change in absorbance at $340 \mathrm{~nm}$ was monitored by a spectrophotometer. Activity was expressed as units per mg protein. 


\section{Measurement of MDA levels}

The tissue MDA levels were determined by the method of Draper and Hadley (1990) based on the reaction of MDA with thiobarbituric acid (TBA) at 95 $8 \mathrm{C}$. In the TBA test reaction, MDA and TBA react to form a pink pigment with an absorption maximum at $532 \mathrm{~nm}$. The reaction was performed at $\mathrm{pH} \mathrm{2-3}$ at $95^{\circ}$ $\mathrm{C}$ for $15 \mathrm{~min}$. The sample was mixed with 2.5 volumes of $10 \%(\mathrm{w} / \mathrm{v})$ trichloroacetic acid to precipitate the protein. The precipitate was pelleted by centrifugation and supernatant was reacted with $0.67 \%$ TBA in a boiling water-bath for $15 \mathrm{~min}$. After cooling, the absorbance was read at $532 \mathrm{~nm}$. Results were expressed as $\mathrm{nmol} / \mathrm{mg}$ tissue.

\section{II- Histopathological study}

Hippocampus samples were fixed in $10 \%$ formaline saline. Paraffin sections of $5 \mu \mathrm{m}$ thickness were prepared, stained with haematoxylin ( $\mathrm{Hx})$ and eosin $(\mathrm{E})$ stain and examined by light microscope (Bancroft, and Steven, 2002).

\section{III- Immunohistochemistry for Glial fibrillary acidic protein (GFAP)}

Immunohistochemistry was performed by following the method of Ramos-Vara et al.(2008). The paraffin sections were processed by Streptavidin-biotin complex (Strep ABC) paraffin sections were deparaffinized in xylene, hydrated and then placed in phosphate buffered saline (PBS; pH 7.6). Antigen retrieval was performed by boiling for 15 minutes in citrate buffer $(0.01 \mathrm{M})$. Sections were treated with $3 \%$ hydrogen peroxide for 5 minutes to quench endogenous peroxidase activity, rinsed with deionized water and then washed with PBS. Sections were incubated first with $1 \%$ pre-immune rabbit serum to decrease non-specific staining and then with a monoclonal antibody against GFAP (Dako, Carpinteria CA, USA) at $23{ }^{\circ} \mathrm{C}$ in a moist chamber for 1 hour. Detection of the antibody was performed using a biotin-streptavidin detection system (Bio-Genex, San Ramon CA, USA) with 3-amino 9-ethyl carbazole (AEC) as chromogen (Dako, Carpinteria CA, USA). Sections were counterstained with Mayer's hematoxylin, sections were evaluated using a light microscope.

\section{IV-Microscopical evaluation for GFAB stained cells}

The number of positive neuronal cells was assessed. Measurements were done within 10 fields for each specimen at X400 magnification. This was achieved by using the Leica Q 500 Image analyzer computer system in the Histology department, Faculty of Medicine, Zagazig University.

\section{V- Statistical analysis}

All the grouped data were statistically evaluated with SPSS, version 10 software. Testing methods included one-way analysis of variance (ANOVA) for comparisons between more than two groups followed by least significant difference (LSD) test for comparison between two groups. Percentage values were analyzed by Chi square test. The level of significance was set at $p<0.05$. All the results were expressed as mean \pm S.D.

\section{Results}

\section{Biochemical results}

No statistically significant changes were observed in the studied biochemical parameters between negative control, distilled water group and GBE group.

Formaldehyde treated rats showed a statistically significant decrease in the activities of SOD, GSH-Px and CAT in hippocampus tissues as compared to their corresponding values in control group. They also showed statistically significant increase in MDA level with $\mathrm{P}<0.05$. The rats that were exposed to FA together with GBE administration had significantly increased SOD, GSH-Px and CAT enzyme levels and decreased MDA level as compared to their corresponding values in FA treated group with $\mathrm{P}<0.05$. Rats treated with FA $+\mathrm{GBE}$ showed nonsignificant change in the levels of SOD, GSH-Px, CAT and MDA in comparison with the control group (Table I).

\section{Histopathological results}

In the control group and the group treated with GBE the morphology of neurons in the hippocampus tissue was nearly normal (Figure 1a) and (Figure 1c) respectively. The most consistent findings in histological sections in FA treated group were the degenerative changes and neuronal loss, shrunken cytoplasm and extensively dark pycnotic nuclei (Figs. 1b). In FA + GBE treated group, the severity of degenerative changes in the cytoplasm and nucleus of hippocampus tissues were less than those in FA group (Figure 1d). Statistical analysis of these pathological changes by Chi square revealed that FA treated rats showed significantly increased changes compared to other groups with $\mathrm{P}<0.05$ (Table II).

\section{Immunohistochemical staining of GFAP results}

The result of GFAP immunohistochemistry has been shown in Figure 2. The number of GFAB positive astrocytes was increased in formaldehyde exposed rats (Figure 2b). In GBE+FA treated group, the GFAPpositive cells were less than FA group (Figure 2d). Statistical analysis of the GFAB results by ANOVA revealed significant increase in GFAB positive astrocytes in formaldehyde treated rats as compared to other groups of the study with $\mathrm{p}<0.05$ (Table III). 
Table (I): A statistical comparison between the negative control group I, group III (received GBE $300 \mathrm{mg} / \mathrm{kg} / \mathrm{day}$ orally), group IV (received FA $0.2 \mathrm{mg} / \mathrm{kg} / \mathrm{day}$ by i.p injection ) and group V( received FA+ GBE in the previously mentioned doses) as regard mean values of SOD, GSH-Px,CAT and MDA in the hippocampus of the adult male albino rats all over the period of the study (4 weeks) by (ANOVA test followed by LSD).

\begin{tabular}{|l|c|c|c|c|c|c|}
\hline \multicolumn{1}{|c|}{ Groups } & $\begin{array}{c}\text { Group I } \\
\text { (negative control ) } \\
\text { Mean } \pm \text { S.D }\end{array}$ & $\begin{array}{c}\text { Group III } \\
\text { (GBE) } \\
\text { Mean } \pm \text { S.D }\end{array}$ & $\begin{array}{c}\text { Group IV } \\
\text { (FA) } \\
\text { Mean } \pm \text { S.D }\end{array}$ & $\begin{array}{c}\text { Group V } \\
\text { (FA+GBE) } \\
\text { Mean } \pm \text { S.D }\end{array}$ & f & P \\
\hline SOD (units/mg protein.) & $14.2 \pm 2.33$ & $12.8 \pm 1.29$ & $7.7 \pm 1.15^{*}$ & $14.4 \pm 2.70$ & 13.43 & $<0.05$ \\
\hline GSH-Px (units/mg protein.) & $74.7 \pm 1.28$ & $69.4 \pm 1.20$ & $50.0 \pm 1.21^{*}$ & $72.5 \pm 4.81$ & 16.36 & $<0.05$ \\
\hline CAT (units/mg protein) & $20.5 \pm 1.91$ & $25.4 \pm 1.30$ & $12.5 \pm 0.89^{*}$ & $19.0 \pm 1.24$ & 15.13 & $<0.05$ \\
\hline MDA (nmol/mg tissue) & $9.3 \pm 0.97$ & $8.4 \pm 1.12$ & $22.5 \pm 2.83^{*}$ & $10.3 \pm 1.29$ & 14.89 & $<0.05$ \\
\hline
\end{tabular}

( ) Significantly different from other groups in the same raw $(P<0.05)$.

N.B: number of rats in each group is six rats.

Table (II): A statistical comparison between the negative control group I, group III (received GBE 300 $\mathrm{mg} / \mathrm{kg} /$ day orally), group IV (received FA $0.2 \mathrm{mg} / \mathrm{kg} /$ day by i.p injection ) and group V( received FA+ GBE in the previously mentioned doses) as regard the histopathological changes in the hippocampus of the adult male albino rats all over the period of the study (4 weeks ) by Chi square.

\begin{tabular}{|c|c|c|c|c|c|c|c|c|c|}
\hline \multirow{2}{*}{$\overbrace{\text { Pathology }}^{\text {Groups }}$} & \multicolumn{2}{|c|}{$\begin{array}{c}\text { Group I } \\
\text { (negative Control) }\end{array}$} & \multicolumn{2}{|c|}{$\begin{array}{l}\text { Group III } \\
\text { (GBE) }\end{array}$} & \multicolumn{2}{|c|}{$\begin{array}{l}\text { Group IV } \\
\text { (FA) }\end{array}$} & \multicolumn{2}{|c|}{$\begin{array}{l}\text { Group V } \\
(\text { FA+GBE) }\end{array}$} & \multirow[t]{2}{*}{$\mathbf{P}$} \\
\hline & No & $\%$ & No & $\%$ & No & $\%$ & No & $\%$ & \\
\hline Degenerated neuron & 0 & 0 & 0 & 0 & 5 & $83.3^{*}$ & 1 & 16.7 & $<0.05$ \\
\hline Shrunken cytoplasm & 0 & 0 & 1 & 16.7 & 4 & $66.7^{*}$ & 1 & 16.7 & $<0.05$ \\
\hline Pycnotic nuclei & 0 & 0 & 1 & 16.7 & 4 & $66.7^{*}$ & 1 & 16.7 & $<0.05$ \\
\hline
\end{tabular}

( ) Significantly different from other groups in the same raw $(P<0.05)$.

N.B: number of rats in each group is six rats.

Table (III): A statistical comparison between the negative control group I, group III (received GBE 300 $\mathrm{mg} / \mathrm{kg} /$ day orally), group IV (received FA $0.2 \mathrm{mg} / \mathrm{kg} /$ day by i.p injection ) and group V( received FA+ GBE in the previously mentioned doses) as regard mean number of GFAB positive astrocytes in the hippocampus of the adult male albino rats all over the period of the study (4 weeks ) by (ANOVA test followed by LSD).

\begin{tabular}{|l|c|c|c|c|c|c|}
\multirow{4}{*}{ Groups } & $\begin{array}{c}\text { Group I } \\
\text { (negative control ) }\end{array}$ & $\begin{array}{c}\text { Group III } \\
\text { (GBE) }\end{array}$ & $\begin{array}{c}\text { Group IV } \\
\text { (FA) }\end{array}$ & $\begin{array}{c}\text { Group V } \\
\text { (FA+GBE) }\end{array}$ & \multirow{2}{*}{ f } & P \\
\cline { 2 - 7 } & $\begin{array}{c}\text { Mean } \pm \text { S.D } \\
\left(\text { cells per } \mathrm{mm}^{2}\right)\end{array}$ & $\begin{array}{c}\text { Mean } \pm \text { S.D } \\
\left(\text { cells per } \mathrm{mm}^{2}\right)\end{array}$ & $\begin{array}{c}\text { Mean } \pm \text { S.D } \\
\left(\text { cells per } \mathrm{mm}^{2}\right)\end{array}$ & $\begin{array}{c}\text { Mean } \pm \text { S.D } \\
\left(\text { cells per } \mathrm{mm}^{2}\right)\end{array}$ & \\
\hline GFAB positive astrocytes & $17.2 \pm 2.33$ & $16.5 \pm 1.29$ & $65.6 \pm 1.15^{*}$ & $23.7 \pm 1.70$ & 18.48 & $<0.05$ \\
\hline
\end{tabular}

( ) Significantly different from other groups $(P<0.05)$.

N.B: number of rats in each group is six rats. 


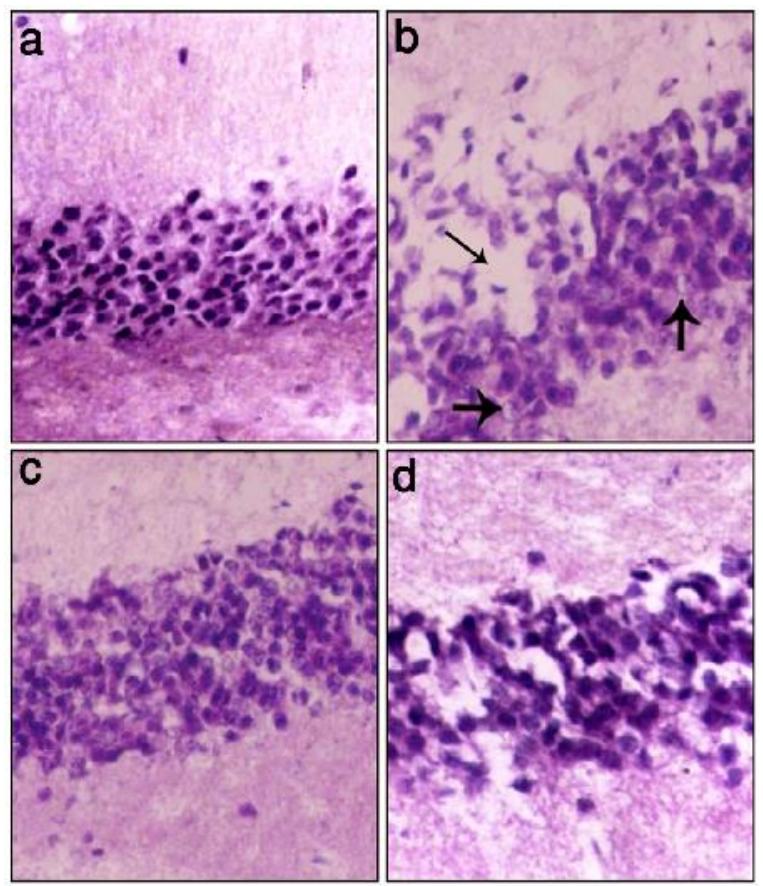

Figure 1: A photomicrograph of hippocampus region of the rat brain of (a) control group showing normal histological picture (b) FA treated group (0.2 $\mathrm{mg} / \mathrm{kg} /$ day by i.p injection for 4weeks) showing loss of cells and vacuolization ( $\downarrow$ ) shrunken cytoplasm $(\uparrow)$ with pycnotic nuclei $(\rightarrow)$ (c) GBE treated group $(300 \mathrm{mg} / \mathrm{kg} / \mathrm{day}$ orally) showing normal histological picture (d) FA+GBE treated rats in the above mentioned doses showing decreased degenerated cells.

(Hx and E X400)

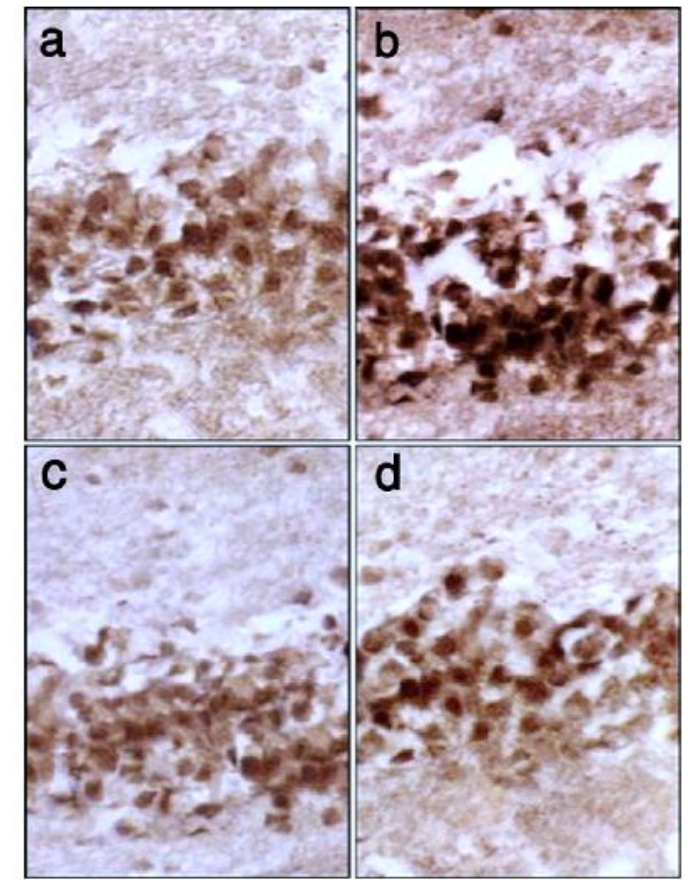

Figure 2: A photomicrograph of immunohistochemical staining of GFAP -stained cells in hippocampus tissue of rat brain (a) control group showing faint staining (b) FA treated group (0.2 $\mathrm{mg} / \mathrm{kg} / \mathrm{day}$ by i.p injection for 4 weeks) showing dark staining (c) GBE treated group (300 mg/kg/day orally for 4weeks) showing faint staining (d) FA +GBE treated rats with the above mentioned doses showing decreased number of GFAP positive cells.

(streptavidin biotin complex X400)

\section{Discussion}

The central nervous system (CNS) is one of the most important systems affected by FA (Tang et al., 2012). The hippocampus is among sites in the brain that coordinates spatial learning and memory. It is also found to be the first brain region affected in age

associated impairments of the brain like Alzheimer's disease. Moreover, hippocampus is also known to respond to sound stimulation and seems to play a role in auditory sensory gating (Abousetta et al., 2014). 
Considering its serious threats to human health, FA has raised concern about public safety. To prevent against FA-induced neurotoxic effects, the mechanisms on the noxious effects of FA should be elucidated.

The body has a defense system to protect against damage induced by oxidative stress. It consists of antioxidant enzymes such as GPx, SOD and CAT. Antioxidant enzymes react directly with oxygen free radicals to yield non-radical products (Gizi et al., 2011).

Whereas SOD catalyzes the conversion of superoxide radicals to hydrogen peroxide, CAT converts hydrogen peroxide into water. Therefore, SOD-CAT system provides the first defense system against oxidative stress and these enzymes work together to eliminate active oxygen species (Wafa et al., 2011).

Glutathione peroxidases are antioxidant selenoenzymes that are present in the cytosol of cells. The major function of these enzymes, which use glutathione (GSH) as a substrate, is to reduce soluble hydrogen peroxide and alkyl peroxidases (Demir et al., 2011).

Malondialdehyde (MDA) has been widely studied as a product of polyunsaturated fatty acid peroxidation (Lee et al., 2014). Under conditions of oxidative stress, free radical-mediated oxidative damage occurs at various sites within the cell such as peroxidation of cellular membrane lipids resulting in the generation of toxic products including MDA (Dias et al., 2013).

In the present study, the hippocampus brain tissue of rats that was exposed to FA had significantly decreased SOD, CAT and GSH-Px activities, which indicates that FA had disrupted the antioxidant defense mechanism in these tissues, causing oxidative damage. Also the MDA levels of FA administered group were significantly higher than those of the controls. This showed that FA had caused lipid peroxidation of the hippocampus tissue; thus, leading to oxidative damage. These results are in agreement with previous study of, Zararsiz et al. (2006 and 2007) who found that exposure to FA led to an increase in the MDA level and a decrease in the activity of SOD and GSH-Px in the rat prefrontal cortex. Tang et al. (2012) demonstrated that oxidative stress is one of the most critical effects of FA exposure on rats hippocampus.

Tulpule et al. (2012) exposed oligodendroglial cells to FA which had severe consequences on the glutathione (GSH) metabolism of these cells. They were reported that FA induces a rapid GSH export from viable oligodendroglial cells. Such FA-induced GSH loss is likely to compromise the cellular antioxidative and detoxifying potential and may contribute to the known neurotoxicity of FA (Songur et al., 2010) and to the reported deficits in memory and learning after FA exposure (Tong et al., 2011).

Additionally, Songur et al. (2008) reported that the effect of FA on cerebellar oxidant/antioxidant systems increased in a dose-related manner and continued for a long time.
Zhang et al. (2013) mentioned that MDA can damage biomolecules, such as proteins and cellular DNA or RNA and can damage cells, such as hippocampal neurons. Levels of MDA in living organisms were found to be significantly modified in the pathological situations. Therefore, detection of MDA is critical to monitor the progression of these diseases and elucidate the underlying pathology mechanism.

The reduction in GSH-Px, CAT and SOD activities provide evidence that these enzymes have acted to protect cells from increased oxidative events.

Furthermore, these activities provide evidence for the involvement of glutathione, since FA is metabolized by FDH and this enzyme is dependent on glutathione. Therefore, it was postulated that FA causes oxidative damage as a general toxic effect. Also, FA neurotoxicity may be mediated by the activation of free radical producing enzymes and by the inhibition or expenditure of free radical scavenger systems, thereby enhancing the production of ROS (Songur et al., 2010).

Brain is particularly prone to damage by reactive oxygen species (ROS) and reactive nitrogen species (RNS) due to five main reasons: the high oxygen required by this organ; the abundance of redoxactive metals; the relative deficit in antioxidant systems; the presence of great amount of oxidizable polyunsaturated fatty acids and catecholamines; and the fact that neurons are post-mitotic cells with relatively restricted replacement by progenitor cells during lifetime (Kim et al., 2013 ; Pereir et al., 2013).

Regarding histopathological study, FA administration caused degenerative changes, shrunken cytoplasm and extensively dark pycnotic nuclei in neurons of the hippocampus tissues. These observations are in agreement with previous studies, which showed that FA treatment caused severe degenerative changes in neurons of frontal cortex and hippocampal tissues (Gurel et al., 2005). Also Lu et al. (2013) reported that FA is capable of causing cell stress responses including cell morphology changes, protein aberrant modifications and even cell death. Moreover exposure of rats to exogenous gaseous formaldehyde induces the accumulation of formaldehyde, decreases the number of hippocampal neurons, neurofilament protein changes and demyelization in hippocampal neurons (Tong et al., 2013). Matsuka et al. (2010) stated that FA has been shown to induce oxidative stress in mouse brain, lung and liver following exposure by inhalation. The increased levels of oxidative stress can induce inflammation and subsequently cell apoptosis

The results of Luo et al. (2012) have been demonstrated that FA has negative effects on central nervous system. Long-term exposure to FA may lead to irreversible neurotoxicity. The suggested mechanism is that FA actually induces Endoplasmic reticulum (ER) stress. Severe ER stress causes cell death.

Glial fibrillary acidic protein (GFAP), as a specific marker of differentiated astrocyte in the central nervous system (CNS), is used to detect the 
morphological and functional alterations of astrocytes involved in brain damage (Wang et al., 2012 b).

The results of the present study showed that, as compared to the control group, GFAP immunoreactivity was markedly enhanced in the hippocampus of the FA group. In accordance with these results Dou et al (2012) who reported that GFAP immunoreactivity was markedly enhanced in formaldehyde exposed mice and GFAP-positive hippocampus cells increased with positive granules. Tong et al (2011) showed that excessive formaldehyde induces changes in neurofilament proteins in hippocampal neurons.

Astrocyte processes envelope neuronal synapses. There is ample evidence that astrocytes are actively involved in modulating synaptic transmission (Halassa and Haydon, 2010; Lee et al., 2012). In response to damage inflicted to the central nervous system, astrocytes can change into a so-called reactive state. This transition termed astrogliosis is characterized by an increase in the expression of their main intermediate filament GFAP by morphological alterations (hypertrophy) and by functional changes (Verkhratsky et al., 2010; Vincent et al., 2010). Intermediate filaments are dynamic structures that are involved in a range of cellular processes during homeostasis and stress (Feneberg et al., 2013).

The elevation of GFAB expression in astrocytes in FA-treated group usually is a response to sustained injury.

Neurotoxicity of FA is connected with overproduction of intracellular reactive oxygen species (ROS). As well as with many other types of intoxications associated with the overproduction of ROS, a promising area of search for potential bioprotectors against formaldehyde toxicity lies with antiradical/antioxidant action (Katsnelson et al., 2013).

Free radicals are well known for their dual role as beneficial and toxic components, higher levels of free radicals causing damage to cellular proteins, membrane lipids and nucleic acids leads to cell death. Antioxidants are effective against free radicals by donating their own electrons (Mazumder et al., 2012).

Ginkgo products have long been used in traditional medicine to treat blood disorders and improve memory. They are commercially available in leaves, standardized extracts, tablets, capsules, and teas (Liu et al., 2014).

In the current study the concomitant administration of GBE with Formaldehyde resulted in a significant increase in the activity of GPX, SOD and CAT enzymes and a significant decrease in MDA. These findings support the hypothesis that GBE could possess a neuroprotective effect against FA-induced neurotoxicity. These actions could be mediated through its antioxidant free radical scavenging and antilipoperoxidative properties (Kasper and Schubert, 2009). Kaur et al. (2013) showed that GBE caused significant decrease in oxidative stress as assessed by MDA levels and increase in the antioxidant enzymes (GPX, total glutathione, CAT and SOD) which were depressed by trimethyltin.
Mechanisms of action of GBE also include inhibiting beta-amyloid aggregation, attenuating betaamyloid-induced neurotoxicity, scavenging free radicals, and promoting cerebral blood flow (Lau et al., 2013). Meanwhile Kaur et al. (2013) stated that although the mechanisms underlying the neuroprotective actions of GBE are unclear, there is some evidence showing that GBE can regulate the levels of neurotransmitters, such as serotonin, influence neurotransmitter receptors, regulate structural changes in hippocampal circuitry, affect neuronal excitability and trigger neurogenesis in the hippocampus.

The results of the present study also revealed that GBE lead to marked attenuation of FA induced histopathological changes. Additionally, the density of immunohistochemically.-stained cells was minimal in this group. This could be attributed to its antioxidant effect that is expected to protect neural tissue from damage caused by reactive oxygen metabolites liberated during exposure to formaldehyde. These results are supported by previous reports of Yang et al. (2013) who revealed a highly neuroprotective effects of Ginkgo biloba extract against cerebral ischemia/reperfusion. Moreover, GBE also protected brain; tissue against aluminum induced oxidative damage in rats (Abd-Elhady et al., 2013) and protected hippocampus against noise (Abousetta et al., 2014).

Kaur et al. (2013) reported that prophylactic treatment of Ginkgo biloba extract protected against the trimethyltin induced neurodegenration

Diamond and Bailey (2013) stated that Ginkgo biloba special extract is used in most randomized control trials. Indications include cognition and memory in Alzheimer disease, age-associated dementia, cerebral insufficiency, intermittent claudication, schizophrenia, and multi-infarct dementia.

\section{Conclusion and recommendations}

In conclusion, this study has been shown that various biochemical and histological abnormalities are produced in the hippocampus tissues in response to the administration of Formaldehyde to adult male albino rats. These effects included oxidative damage and impairment of structure and function of neurons and appear to be mediated through the production of free radicals. Pre-treatment with GBE offered protection against such changes. Prevention of professional and environmental exposure to FA plays an important role for health care. The discovery of the protective effects of GBE on hippocampus cell injury might carry prophylactic effects against consequences of FA exposure. It should be kept in mind that results obtained from experimental animals should be interpreted cautiously when applied to humans.

\section{References}

Abd-Elhady RM, Elsheikh AM, and Khalifa AE (2013) Anti-amnestic properties of Ginkgo biloba extract on impaired memory function induced by aluminum in rats. Int $\mathrm{J}$ Dev Neurosci.; 31(7):598-607. 
Abousetta A, Makhlouf NA, and El-Beshbishy RA (2014): The effects of concomitant Ginkgo intake on noise induced Hippocampus injury. Possible auditory clinical correlate. EJENTAS; 15: 231-239.

Afifi N M and Hanon AF (2011): Histological and immunohistochemical study on the possible cardioprotective role of acetylcysteine in oral formalin myocardial toxicity in adult albino rats. Egy. J Histol; 34(4):859-869.

Amaral D and Lavenex P (2006): "Ch III. Hippocampal Neuroanatomy". In Andersen P, Morris R, Amaral D, Bliss T, O'Keefe J. The Hippocampus Book. Oxford University Press. ISBN 978-0-19-510027-3.

Bancroft GD and Steven SA (2002): Theory and practice of histochemical technique, $24^{\text {th }}$ edition, Churcull, Livingston, PP. 65-72.

de Groot AC, Flyvholm MA, Lensen G et al. (2009): Formaldehyde-releasers: Relationship to formaldehyde contact allergy. Contact allergy to formaldehyde and inventory of formaldehyde-releasers. Contact Derm.; 61: 63-85.

Demir F, Uzun FG, Durak D et al. (2011): Subacute chlorpyrifos-induced oxidative stress in rat erythrocytes and the protective effects of catechin and quercetin. Pestic. Biochem. Phys.; 99: 77-81.

Diamond BJ and Bailey MR (2013): Ginkgo biloba. Indications, mechanisms and safety. Psych. Clin. North Am, 36: 73-83.

Dias V, Junn E and Mouradian MM (2013): The Role of Oxidative Stress in Parkinson's Disease. J Parkin. Dis; 3(4): 461-491.

Doane M and Sarenbo S (2014): Exposure of farm laborers and dairy cattle to formaldehyde from footbath use at a dairy farm in New York State. Sci., Total Environ; 487:65-71.

Dou X, Zhang Y and Wu Y (2012): Study on Neurotoxicity of Formaldehyde in Mice. Toxicol. Environ. Heal. Sci.; 4: 115-120.

Draper H and Hadley M (1990): Malondialdehyde determination as index of lipid peroxidation. Meth. Enzymol; 186: 421-431.

Farbiszewiski R, Witek A, and Skrzydlewska E (2000): $\mathrm{N}$-acetylcysteine or trolox derivative mitigate the toxic effect of methanol on the antioxidant system of rat brain. Toxicol; 156: 47-55.

Feneberg E, Steinacker P, Lehnert S et al. (2013): Elevated glial fibrillary acidic protein levels in the cerebrospinal fluid of patients with narcolepsy. Sleep Med; 14: 692-694.

Gizi A, Papassotiriou I, Apostolakou F et al. (2011): Assessment of oxidative stress in patients with sickle cell disease: The glutathione system and the oxidant-antioxidant status. Blood Cells, Molec, Dis.; 46: 220-225.

Golden R and Valentini M (2014): Formaldehyde and methylene glycol equivalence: Critical assessment of chemical and toxicological aspects. Regul. Toxicol. Pharmacol; 69: 178186.
Gurel A, Coskun O, Armutcu F, et al. (2005): Vitamin $\mathrm{E}$ against oxidative damage caused by formaldehyde in frontal cortex and hippocampus: Biochemical and histological studies. J Chem. Neuroana ; 29: 173-178.

Halassa MM and Haydon PG (2010): Integrated brain circuits: astrocytic networks modulate neuronal activity and behavior, Ann. Rev. Physiol.; 72: 335-355.

Jain SP, Redasani VK and Kalaskar M.G (2011): Protective effect of Ginkgo biloba on ethanolinduced immunosuppression in rats, Eur J Exp Biol; 1: 83-89.

Johansson LH and Borg H (1988): A spectrophotometric method for determination of catalase activity in small tissue samples. Anal. Biochem; 174: 331-336.

Kasper S and Schubert H (2009): Ginkgo Biloba extracts $\mathrm{EGb} 761(\mathrm{R})$ in the treatmentof dementia: evidence of efficacy and tolerability. Fortschritte der NeurologiePsychiatrie; 77: 494-506.

Katsnelson BA, Degtyareva TD, Privalova LI et al. (2013): Attenuation of subchronic formaldehyde inhalation toxicity with oral administration of glutamate, glycine and methionine. Toxicol. Lett.; 220: 181-186.

Kaur S, Chhabra R and Nehru B (2013): Ginkgo biloba extract attenuates hippocampal neuronal loss and cognitive dysfunction resulting from trimethyltin in mice. Phytomed; 20: 178- 186.

Kim HG, Lee JS, Han JM et al. (2013): Myelophil attenuates brain oxidative damage by modulating the hypothalamus-pituitaryadrenal (HPA) axis in a chronic cold-stress mouse mode. J Ethnopharmacol; 148:505514.

Lau AJ, Yang G, Rajarama G et al. (2013): Evaluation of Ginkgo biloba extract as an activator of human glucocorticoid receptor. J Ethnopharmacol; 145: 670-675.

Lee HU, Yamazaki Y, Tanaka KF et al. (2012): Increased astrocytic ATP release results in enhanced excitability of the hippocampus. Glia; 61: 210-224.

Lee JS, Shin JH, Hwang J-H et al. (2014): Malondialdehyde and 3-

Nitrotyrosine in Exhaled Breath Condensate in Retired Elderly Coal Miners with Chronic Obstructive Pulmonary Disease. Saf. Heal. Work; 5: 91-96.

Liu XG, Yang H, Cheng XL et al. (2014): Direct analysis of 18 flavonol glycosides, aglycones and terpene trilactones in Ginkgo biloba tablets by matrix solid phase dispersion coupled with ultra-high performance liquid chromatography tandem triple quadrupole mass spectrometry. J Pharmaceut. Biomed. Anal.; 97: 123-128.

Liu Y, Ye Z, Yang H et al. (2010): Disturbances of soluble N-ethylmaleimide-sensitive factor attachment proteins in hippocampal synaptosomes contribute to cognitive 
impairment after repetitive formaldehyde inhalation in male. Neurosci; 169: 1248-1254.

Lu J, Miao J, Su T et al. (2013): Formaldehyde induces hyperphosphorylation and polymerization of Tau protein both in vitro and in vivo. Biochim. Biophys. Acta; 1830: 4102-4116.

Luo F-C, Zhou J, Lv T et al. (2012): Induction of endoplasmic reticulum stress and the modulation of thioredoxin-1 in formaldehydeinduced neurotoxicity. Neuro Toxicol; 33: 290-298.

Maiellaro M, Correa-Costa M, Vitoretti L B et al. (2014): Exposure to low doses of formaldehyde during pregnancy suppresses the development of allergic lung inflammation in offspring. Toxicol. Appl. Pharmacol; 278: 266-274.

Matsuoka T, Takaki A, Ohtaki H et al. (2010): Early changes to oxidative stress levels following exposure to formaldehyde in ICR mice. J Toxicol Sci; 35: 721-730.

Mazumder PM, Rathinavelusamy P, and Sasmal D (2012): Role of antioxidants in phytomedicine with special reference to antidiabetic herbs. Asian Pacific J Trop. Dis; 2: S969-S979.

Meng Q, Han T, Wang G et al. (2014): Preparation of a natural dye doped Ormosil coating for the detection of formaldehyde in the optical gas sensor. Sens. Actu. B Chem.; 196:238-244.

Mengome LE, Voxeur A, Akue JP et al. (2014): Screening of antioxidant activities of polysaccharides extracts from endemic plants in Gabon. Bioac. Carbohy. Diet. Fibre; 3: 7788.

Misra HP and Fridovich I (1972): The role of superoxide anion in the autoxidation of epinephrine and a simple assay for superoxide dismutase. J Biol. Chem.; 247: 3170-3175.

Mitkusa RJ, Hessb MA and Schwartz SL (2013): Pharmacokinetic modeling as an approach to assessing the safety of residual formaldehyde in infant vaccines. Vaccine; 31: 2738-2743.

Naidu MUR, Shifow AA, Kumar KV et al. (2000): Ginkgo biloba extract ameliorates gentamicininduced nephrotoxicity in rats. Phytomed; 7 : 191-197.

Odeigah PGC (1997): Sperm head abnormalities and dominant lethal effects of formaldehyde in albino rats. Mut. Res.; 389: 141-148.

Paglia DE and Valentine WN (1967): Studies on quantitative and qualitative characterization of erythrocyte glutathione peroxidase. J. Lab. Clin. Med.; 70:158-169.

Pearce J (2001): "The effects of telencephalic pallial lesions on spatial, temporal, and emotional learning in goldfish". J Neurol. Neuros. Psy; 71: 351-355.

Pereir E, Barros L and Ferreira CFR (2013): Chemical characterization of Ginkgo biloba L. and antioxidant properties of its extracts and dietary supplements. Ind. Corp prod.; 51: 244-248.
Ramos-Vara, JA, Kiupel M, Baszler T et al. (2008): Suggested guidelines for immunohistochemical techniques in veterinary diagnostic laboratories. J. Vet. Diagn. Invest; 20: 393-413.

Songur A, Ozen OA and Sarsilmaz M (2010): The toxic effects of formaldehyde on the nervous system. Rev. Environ. Contam. Toxicol.; 203: 105-118.

Songur A, Sarsilmaz M, Ozen OA et al. (2008): The effects of inhaled formaldehyde on oxidant and antioxidant systems of rat cerebellum during the postnatal development process. Toxicol. Mech. Meth.; 18: 569-574.

Sugiyama T, Kubota Y, Shinozuka K et al., (2004): Induction and recovery of hepatic drug metabolizing enzymes in rats treated with Ginkgo biloba extract. Food Chem. Toxicol.; 42: 953-957.

Tang X-Q, Fang H-R, Zhou C-F et al. (2013): A Novel Mechanism of Formaldehyde Neurotoxicity: Inhibition of Hydrogen Sulfide Generation by Promoting Overproduction of Nitric Oxide. PLOSONE; 1 (8): 1-11.

Tang X-Q, Ren Y-k, Zhou C-F et al. (2012): Hydrogen sulfide prevents formaldehydeinduced neurotoxicity to PC12 cells by attenuation of mitochondrial dysfunction and pro-apoptotic potential. Neurochem. Int.; 61: 16-24.

Tong Z, Han C, Luo W et al. (2013): Accumulated hippocampal formaldehyde induces agedependent memory decline. Age; 35: 583-596.

Tong Z, Zhang J, Luo W et al. (2011): Urine formaldehyde level is inversely correlated to mini mental state examination scores in senile dementia. Neurobiol., Aging; 32: 31-41.

Tulpule $\mathrm{K}$ and Dringen R (2013): Formaldehyde in brain: an overlooked player in neurodegeneration. J Neurochem.; 127(1):7-21.

Tulpule K, Schmidt MM, Boecker K et al. (2012): Formaldehyde induces rapid glutathione export from viable oligodendroglial OLN-93 cells. Neurochem. Int.; 61: 1302-1313.

Verkhratsky A, Olabarria M, Noristani $\mathrm{HN}$ et al. (2010): Astrocytes in Alzheimer's disease. Neurotherap; 7: 399-412.

Vincent AJ, Gasperini R, Foa L et al. (2010): Astrocytes in Alzheimer's disease: emerging roles in calcium dysregulation and synaptic plasticity. J. Alzheimers Dis.; 22: 699-714.

Wafa T, Amel N, Issam C et al. (2011): Subacute effects of 2, 4-dichlorophenoxyacetic herbicide on antioxidant defense system and lipid peroxidation in rat erythrocytes. Pestic. Biochem. Phys; 99: 256-264.

Wang Q, Ishikawa T, Michiue T et al. (2012b): Evaluation of human brain damage in fatalities due to extreme environmental temperature by quantification of basic fibroblast growth factor (bFGF), glial fibrillary acidic protein (GFAP), S100 $\beta$ and 
single-stranded DNA (ssDNA) immunoreactivities. Forensic Sci. Int.; 219: 259-264.

Wang T, Gao X, Tong J et al. (2012a): Determination of formaldehyde in beer based on cloud point extraction using 2,4-dinitrophenylhydrazine as derivative reagent. Food Chem; 131: 15771582.

Xiong XJ, Liu W, Yang XC et al. (2014): Ginkgo biloba extract for essential hypertension: A systemic review. Phytomed; 21: 1131-1136.

Yang Y, Liu P, Chen L et al. (2013): Therapeutic effect of Ginkgobiloba polysaccharide in rats with focal cerebral ischemia/reperfusion (I/R) injury. Carbohy. Polym; 98: 1383- 1388.

Yeh T-S, Lin T-C, Chen C-C et al. (2013): Analysis of free and bound formaldehyde in squid and squid products by gas chromatography-mass spectrometry. J. Food Drug Anal.; 21: 190197.

Zararsiz I, Kus I, Akpolat N et al. (2006): Protective effects of omega-3 essential fatty acids against formaldehyde induced neuronal damage in prefrontal cortex of rats. Cell Biochem. Funct; 24: $237-44$.

Zararsiz I, Kus I, Ogeturk M et al. (2007): Melatonin prevents formaldehyde-induced neurotoxicity in prefrontal cortex of rats: an immunohistochemical and biochemical study. Cell Biochem Funct; 25(4): 413-8.

Zeng Z, Qi C, Chen Q et al. (2014): Absorption and metabolism of formaldehyde in solutions by detached banana leaves. J. Biosci. Bioeng; 117:602-612.

Zhang G, Tang Y, Shi X et al. (2013): A chemiluminescence method to detect malondialdehyde in plasma and urine. Anal. Biochem; 443: 16-21.

\section{الملخص العربى}

\section{تأثير مستخلص أور اق الجنكه بيلوبا على بعض الآثار السمية المحدثة بالفورمالدهيد في حصينذ كور الجرذان

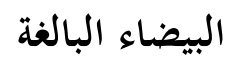

\section{أمل محمد عبد الخالق' و أمل الشحات إبراهيم}

يعد مركب الفورمالدهيد من المركبات واسعة الانتشار في المستحضرات التي تستخدم في حياتنا اليومية، فهو يدخل في تركيب العديد من المن المبات

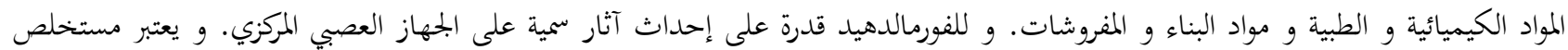
أوراق الجنكه من مضادات الأكسدة ذات التأثير الفعال .

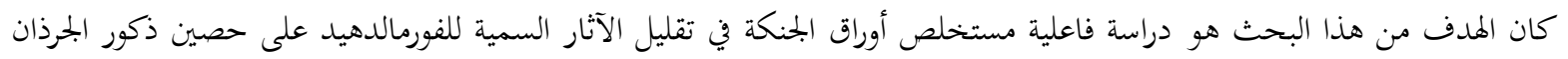

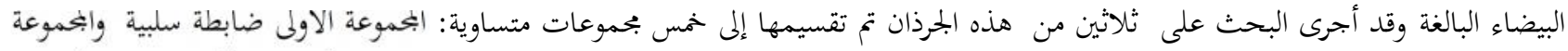

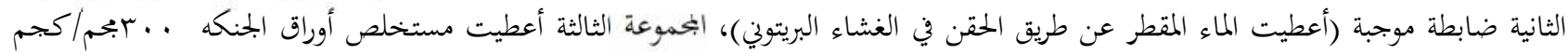

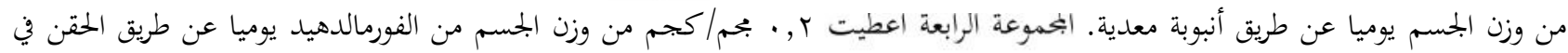

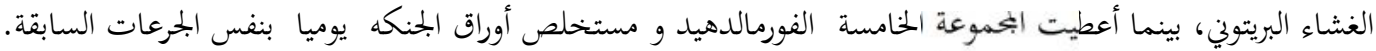

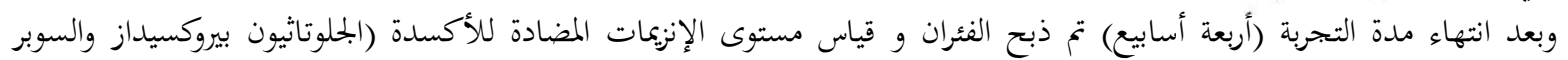

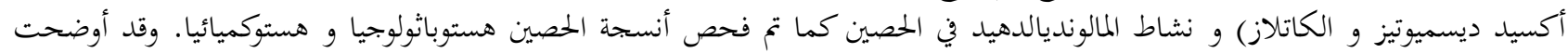

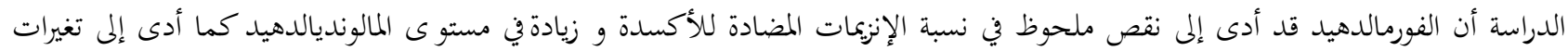

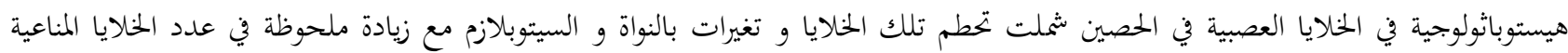

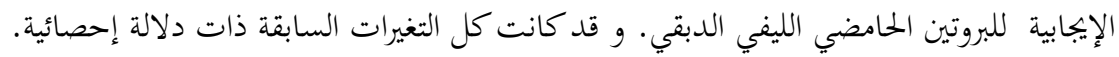

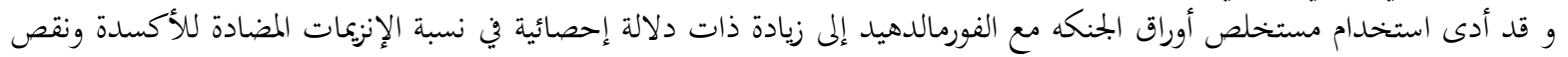

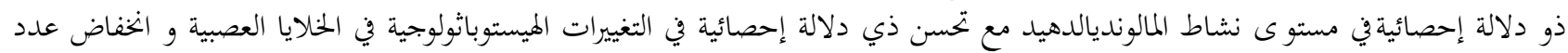

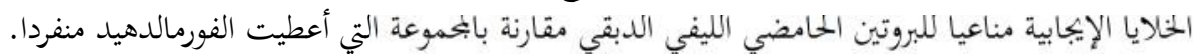

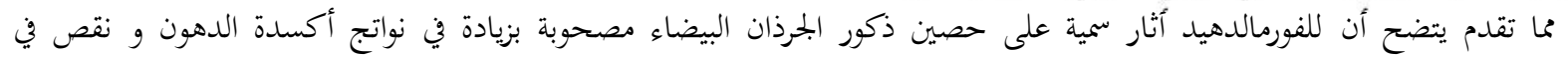

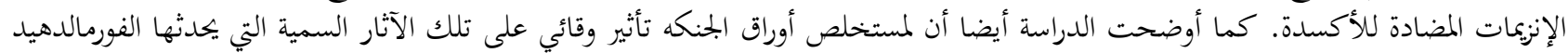
في حصين ذكور الجرذان البيضاء البالغة لذا يوصي باستخدامه عند التعرض للفورمالدهيد لتقليل آثاره السمية. 